\title{
ANZTLA Affairs
}

Work is proceeding on the preparation of the 1998 Conference and most of the details are now arranged. The brochures for registration should have been received by members by the time this Newsletter arrives. As a reminder the Conference is on from lst to 5th Judy at Moore Theological College in Newtown, Sydney. If anyone has not received the registration forms please contact either Jocelyn Morris (02-9683 3655) or myself.

At the Conference we will be presenting our third Honorary Life Membership and also there will be a presentation of the Trevor Zweck Award. These awards allow the Association to show its appreciation for work done on its behalf.

Chapters should have received information from Tony McCumstie concerning possible guidelines for future editions of AULOTS, Can I encourage each chapter to look seriously at these guidelines and to respond to Tony with any comments prior to our Conference. We will have this matter on the agenda of the AGM and it will help with the meeting if most of the thinking on this matter has been done at chapter level and not on
the floor of the AGM.

In March I was able to attend the first Executive Meeting of the Forum of Asian Theological Librarians in Taipei. We spent much of the meeting working on a draft Constitution and on the production of a promotional brochure. The member from Korea was unable to attend the meeting due to the financial crisis in her country. I feel that the potential for cooperation between libraries in the area is unlimited and that this cooperation will produce access to an invaluable resource of material that presently is mainly known only in the originating country. In visiting the host library and others during my time away I was struck by the amount of material which, to my knowledge, is seldom seen in either Australia or New Zealand. I begin to see more clearly the concern which Rita and John England (who were instrumental in the formation of ForATL) have over the dissemination of Asian theological resources.

Kim Robinson

President 